\title{
Systematic Study of Acanthochlamydaceae---A New Endemic Family of China
}

\author{
Gao Bao-Chun (Kao Pao-Chun) \\ Chengdu Institute of Biology, Chinese Academy of Sciences, China
}

Copyright $(2017$ by authors, all rights reserved. Authors agree that this article remains permanently open access under the terms of the Creative Commons Attribution License 4.0 International License

\begin{abstract}
Acanthochlamys bracteata is a Chinese endemic plant that first discovered, descripted and denominated by Kao in the West Hengduan Mountains of Sichuan Province. The anatomical characteristics of $A$. bracteata are very unique in monocotyledonous plants, such as the eustele in rhizome, protostele in root, as well as the leaf-stem compound structure in scape, which is the most special type in monocotyledonous plants, for the first time found. The coexistence of eustele and protostele in vascular bundle system suggested that Acanthochlamydaceae retains the ancestor of the original type, but also evolved derived type. It is absent of scattered bundles, which is the most derived bundles type in monocotyledons, but shows a transitional type between protostele and scattered bundles. The family, Acanthochlamydaceae, is a new monotypic family, which contains only one species. Phylogenetic results showed that Acanthochlamydaceae is a sister group of Velloziaceae. The close relationship with the two families indicated that the close floral relationship between Hengduan mountains and African tropical regions. In this paper, a comprehensive study was performed on the morphological characteristics, the status in the world flora, geographical distribution, phylogeny, origin, and other issues of Acanthochlamys bracteata.
\end{abstract}

Keywords Acanthochlamydaceae, Acanthochlamys bracteata, Multi-discipline Studies, Velloziaceae

\section{Introduction}

Acanthochlamydaceae is established by the author in 1989 based on Acanthochlamys P.C. Kao [1]. The family contains only one endemic species, Acanthochlamys bracteata P.C. Kao. Monotypic family is rarely found in the floristics research of seed plants in China, and is also uncommon in the research of world Angiosperm flora. Studying this group is significantly helpful to understand the origin and evolution of angiosperms and biogeographic changes.
Acanthochlamys is a dwarf caespitose perennial herb. Inflorescences of Acanthochlamys have epigynous flowers with pre-floral stage, spiral ptyxis and up to 18 spirally arranged bracteoles on the pedicel. The anthers are bisporangiate. The separation of the staminal-carpellary complex at the base of the hypanthium as seen in other monocots has not been observed. Dorsal carpellary trace appears in the upper region of the ovary and staminal appears in free portion of the hypanthium, at the same level where the short filament is attached. The vegetative organization is unique among vascular plants. There are no buds in the axils of the spirally arranged leaves. The adventitious roots can be triarch or tetrarch. The stem, unlike all other seed plants, does not form vascular bundles. The phloem appears dispersed among the xylem elements, without any organized arrangement. Protoxylem elements are only observed next to the stem medulla. The emergence of a leaf trace or adventitious root connects the cortex with the medulla and determines the division of the vascular cylinder into three parts, which later separate into leaves (two-regions) and floral scape, only structure that exhibits six vascular bundles. The whole complex is surrounded by the same fibre sheath which appears in the main axis, but here surrounds each of the subdivisions. The amphistomatic leaf differs from all other monocots, which have a single vascular bundle inner the endodermis, while in Acanthochlamys there are two vascular bundles formed by proto- and metaxylem and proto- and metaphloem inner the unique endodermis, similar to that seen in the leaf of Pinus. The discovery of the Acanthochlamydaceae is a supplement to the ancient plant taxonomy, which has laid a solid foundation for unraveling the mystery of the origin of angiosperms, and will be a challenge to the "artificial classification", which will change people's understanding of the ancient plant groups and promote the concern on "relict plants" and "living fossils" in the world. In this paper, the author gave a comprehensive overview of the morphological characteristics, the status in the world flora, geographical distribution, phylogeny, origin, and other issues of Acanthochlamys bracteata. 


\section{Results and Discussion}

\subsection{Description and Nomenclature}

Acanthochlamydaceae Kao P.C., in Fl.Sichuan.9: 483[2]

Dwarf caespitose; perennial herb (Fig. 1); rhizome short; roots dense, thin and long, fibriform; leaves acerose, dorsiventral, ventrally subsemiorbicular and 2-canaliculate, dorsally flattened and 1-canaliculate, sheathed at the base. Inflorescence a compound capitulum on a scape arising from the rhizome, at the base usually surrounded by 3 leaf like aristate bracts, the peduncle bearing 5-8 few-flowered capitula, the flowers subtended by aristate bractlets. Flowers hermaphroditic, actionmorphic, epigynous, shortly pedicellate; perianth corollinic, pink, tubular; perianth lobes $3+3$, the inner lobes slightly smaller than the outer; stamens $3+3$, borne upon the corolla lobes; filaments short; anthers oblong, bisporangiate, dorsifixed, introrse, dehiscing by longitudinal slits; ovary inferior, syncarpous, in lower part trilocular with axile placentation, in upper part unilocular with parietal placentation; ovules numerous, anatropous, bitegmic; style elongate, with trilobite stigma; fruit capsular, trigonous, shortly rostrate; seeds oblong, brown; endosperm starch containing; embryo large, central.

Only one species Acanthochlamys bracteata P.C. Kao, in grassland nearby bushland of xerophytic valley at an altitude of 2700-3500m in Hengduan Mountains of W Sichuan, (Xiangcheng, Daofu, Qianning) and SE Tibet (Chaya), China. Types were collected from Mount Yazhuo, Commune Yazhuo, Zhaba, Daofu County, Sichuan, China in May 1980. (Accession Number 310, Kao Pao-chun, Types was deposited to herbarium of Chengdu institute of biology, Academia Sinica).

Type genus of family: Acanthochlamys P.C. Kao, Acta Phytotax. Chengdu Inst. Biol. Acta. Sin. 1:1 (1980)

Type species: Acanthochlarmys bracteata P.C. Kao (sp. nov., IBIAEM), description of morphological characters and distribution is the same as family.

\subsection{Vegetative Structures}

The vascular cylinder of the root (Fig. 2A, B) is a tetrarch, rarely triarch, actinostele lacking pith; this low number of xylem rays is unusual in monocotyledons. The root epidermis is formed by elongate cells which bear the root hairs. The cortex is composed of many cell layers and is divided into exodermis, cortex and endodermis. The cells of the pericycle are 1-rowed and densely arranged; the lateral roots originate from them.

The aerial parts are covered by elongate, thick walled epidermal cells and bear sunken stomata (Fig. 4C) which are paracytic. Massive sclerenchyma underlies the epidermis. In the leaves (Figs. 3), the mesophyll (Fig. 3A) lacks differentiation into palisade and spongy tissue. The midrib of the leaf is composed of 2 vascular bundles, which are arranged "back to back" (Fig. 3B, D) with their xylem portions.

The scape (Fig. 4) has on one side a longitudinal groove and hence in transversal section is indistinctly heart-shaped. Its anatomical structure is very peculiar insofar that it has a stele with a central tetrarch vascular cylinder similar to that of the roots, which in the upper portion of the scape disintegrates into 5 or 6 collateral bundles. Outside the stellar tissue the inner part of the cortex is sclerified and underneath the longitudinal groove of the scape the cortex is transversed by 2 obliquely oriented vascular bundles (a leaf trace which supplies an involucral bract), which resemble those forming the leaf midrib but are fused with their xylem portions. The structure of the scape is similar to that of a leaf ensheathing a rhizome. Vessel elements with simple (Fig. 5) perforations and helical thickenings are present in the root, scape and leaf. Raphides and tannin cells are lacking completely [2-5]. 


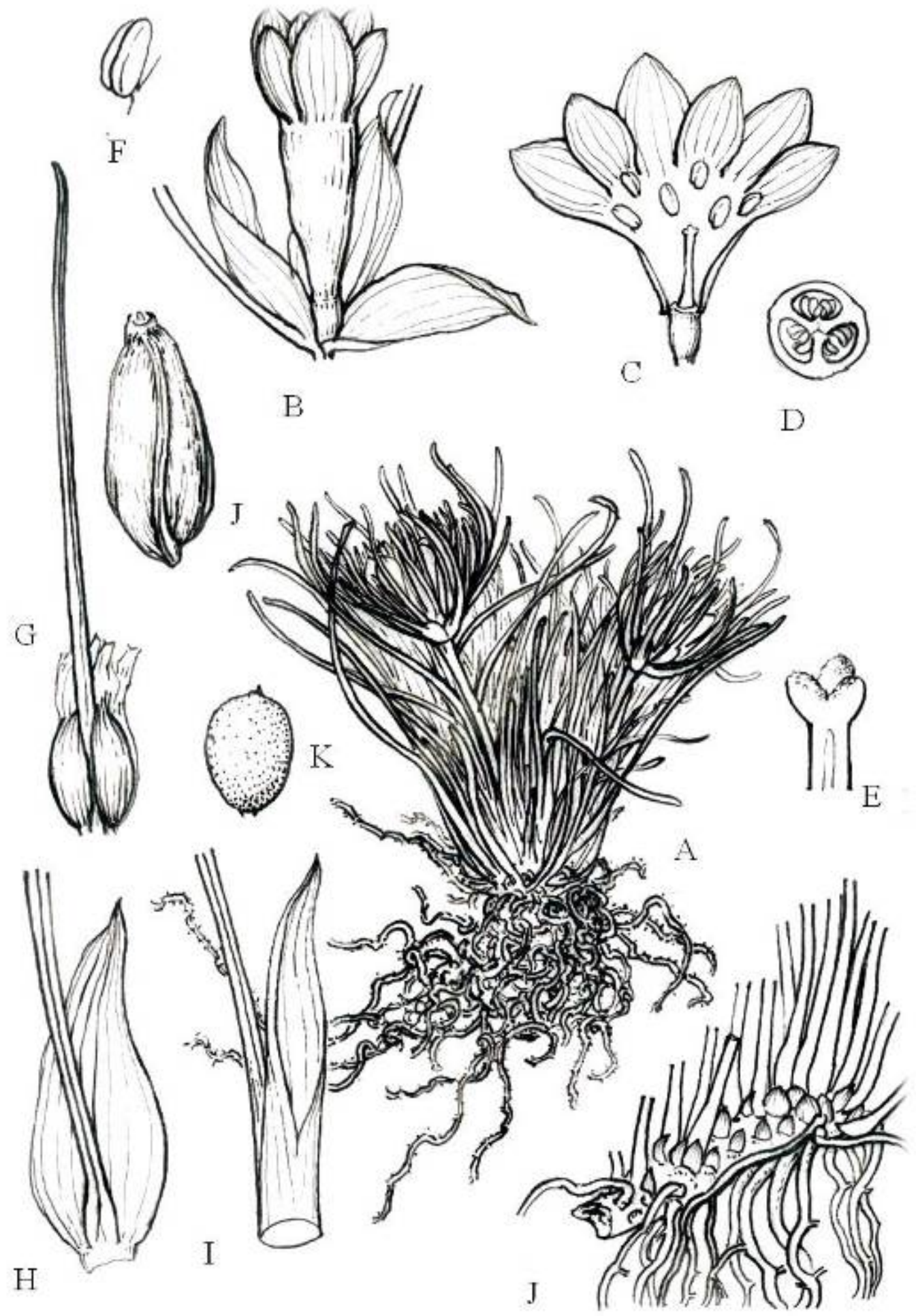

Figure 1. Acanthochlamydaceae. Morphology of Acanthochlamys bracteata (Acanthochlamydaceae): A. Habit. B. Flower. C. Flower, perianth opened. D. Transection of ovary. E. Stigma. F. Anther. G. Flower bract. H, I. leaf sheath. J. Fruit. K. Seed. L. Rhizome.(Drawn byWei Li). 


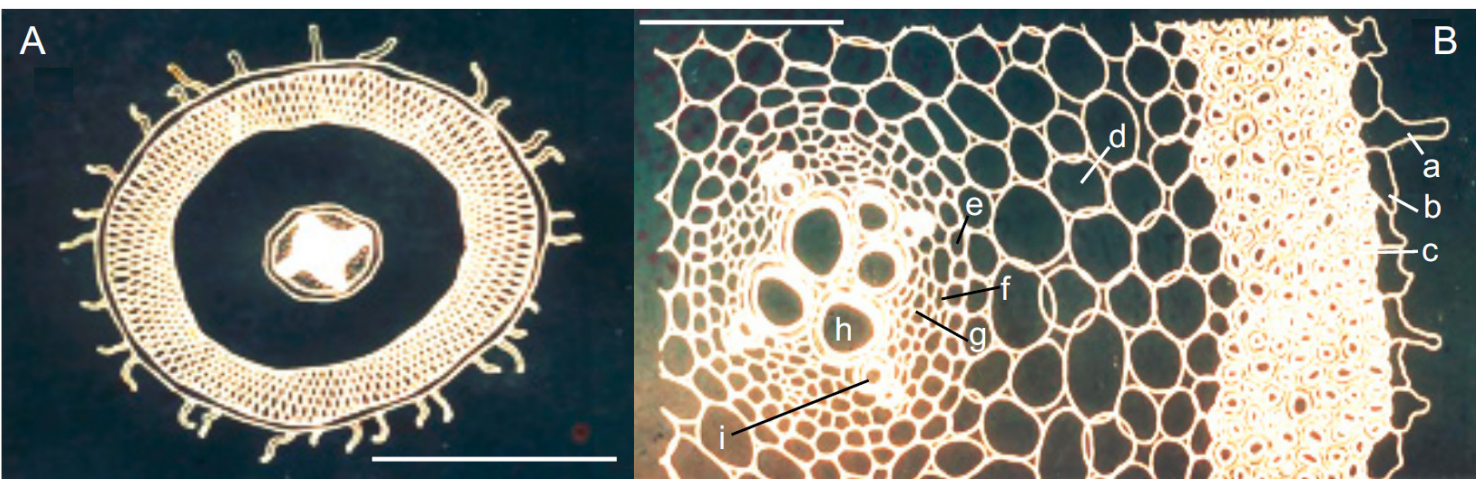

Figure 2. Acanthochlamydaceae. Morphology of transections of Acanthochlamys bracteata root: A. Sketch of root. Bar $=0.25 \mathrm{~mm}$. B. Detail of root. Bar $=50 \mu \mathrm{m}$. $a$. root hair; $b$. epidermis; $c$. exodermis; $d$. cortex; $e$. endodermis; $f$. stele sheath; $g$. phloem; $h$. xylem; $i$. vessel; $j$. sclerenchyma cell.
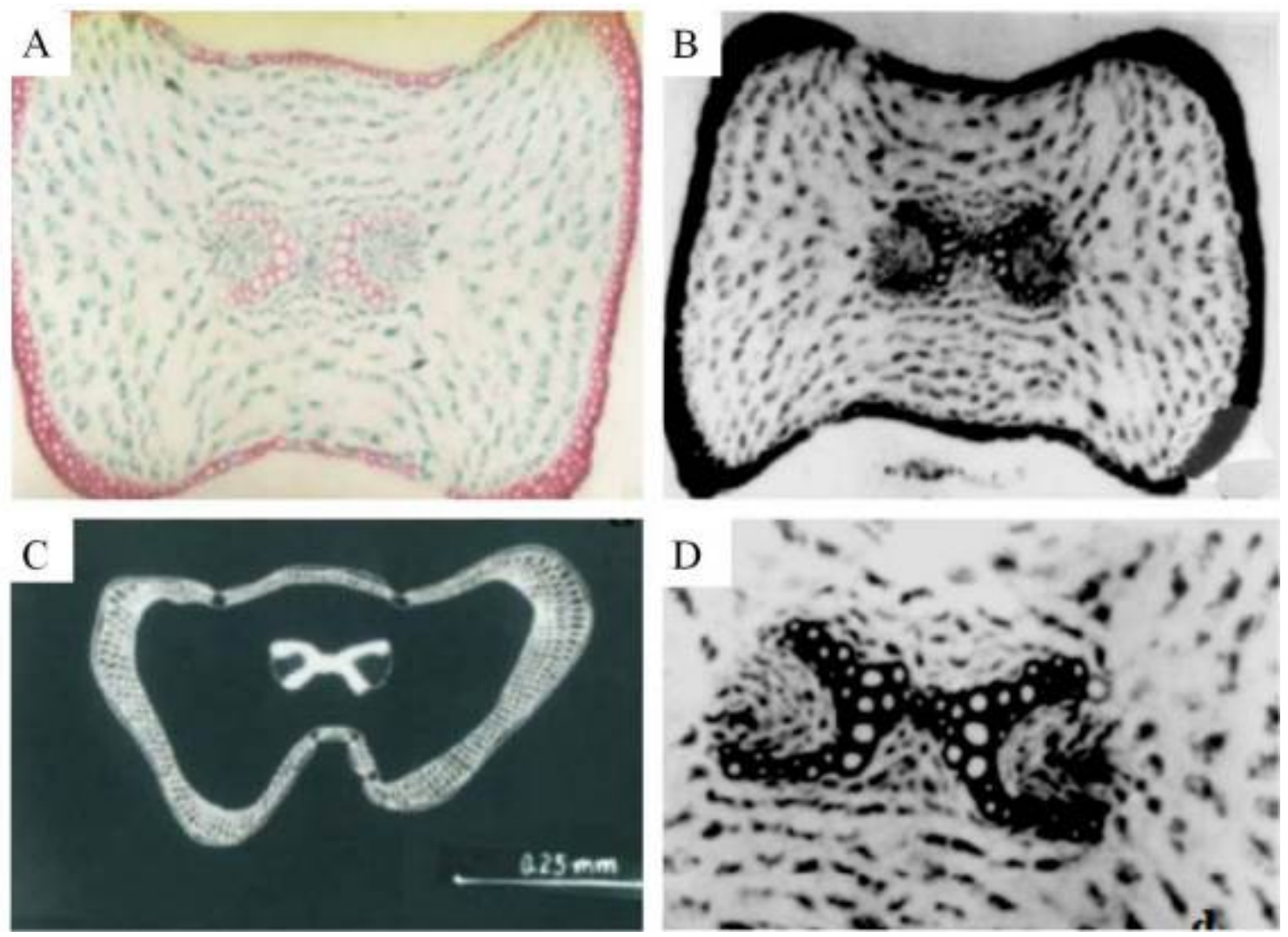

Figure 3. Acanthochlamydaceae. Morphology of transections of Acanthochlamys bracteata leaves: A. Showing the mesophyll lacks differentiation into palisade and spongy tissue. $600 \mathrm{X}$. B. and D. leaf with 2 vascular bundles with their xylem arranged. C. Transverse section of leaflike arista with symmetrically arranged veins with collateral bundles and U-shaped xylem. $800 \mathrm{X}$. 


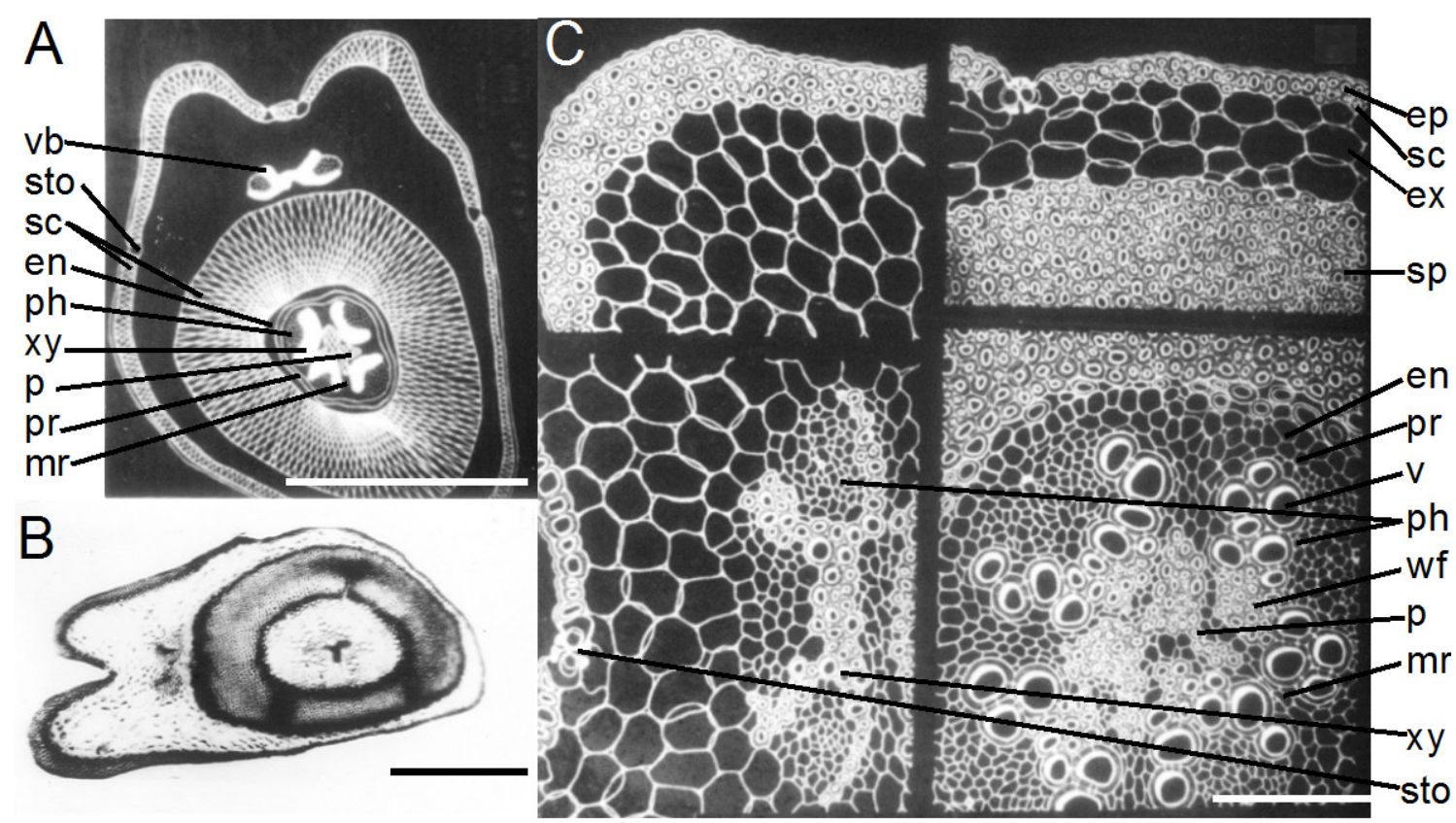

Figure 4. Acanthochlamydaceae. Morphology of Acanthochlamys bracteates cape: A and $\mathbf{B}$. diagram, the structure resembles a compound of leaf and stem. $\mathrm{Bar}=0.25 \mathrm{~mm}$. C. capitals after a period throughout entailed drawing of tissues. Bar $=50 \mu \mathrm{m}$. Ep. epidermis; $v b$. vascular bundle; sto. stoma; sc. sieve cell; en. endodermis; $p h$. phloem; $x y$. xyloem; $p r$. perimedullary region; $p$. parenchyma; $m r$. medullary ray; ex. exodermis; $s p$. secondary phloem; $v$. vessel; $w f$. wood fiber.

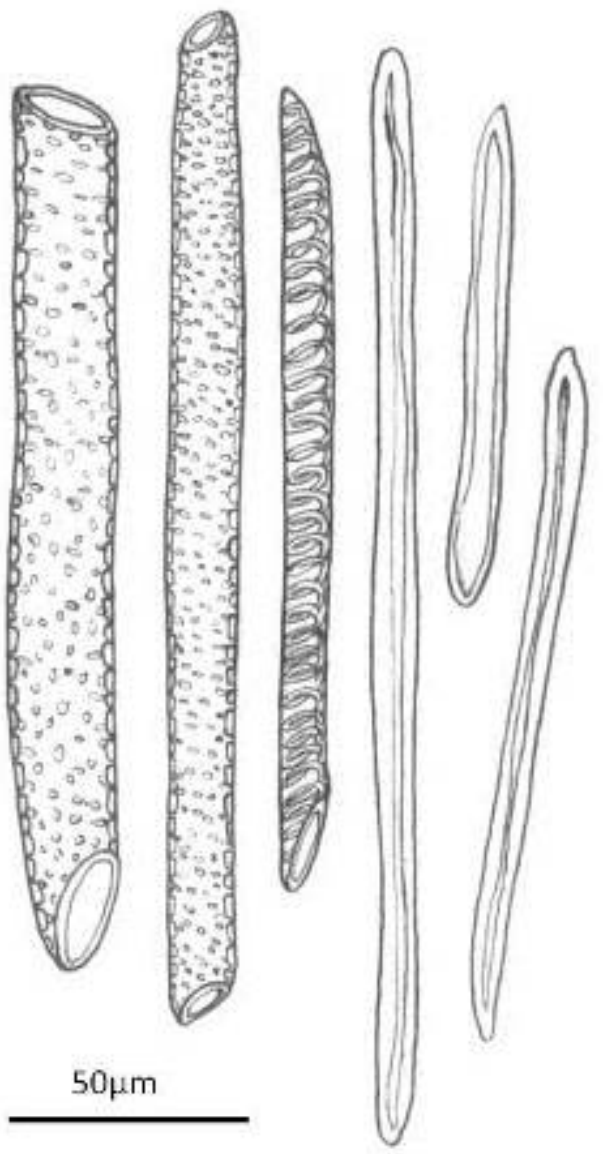

Figure 5. Acanthochlamydaceae. Acanthochlamys bracteata: Vessel elements with simple perforations and helical thickenings 

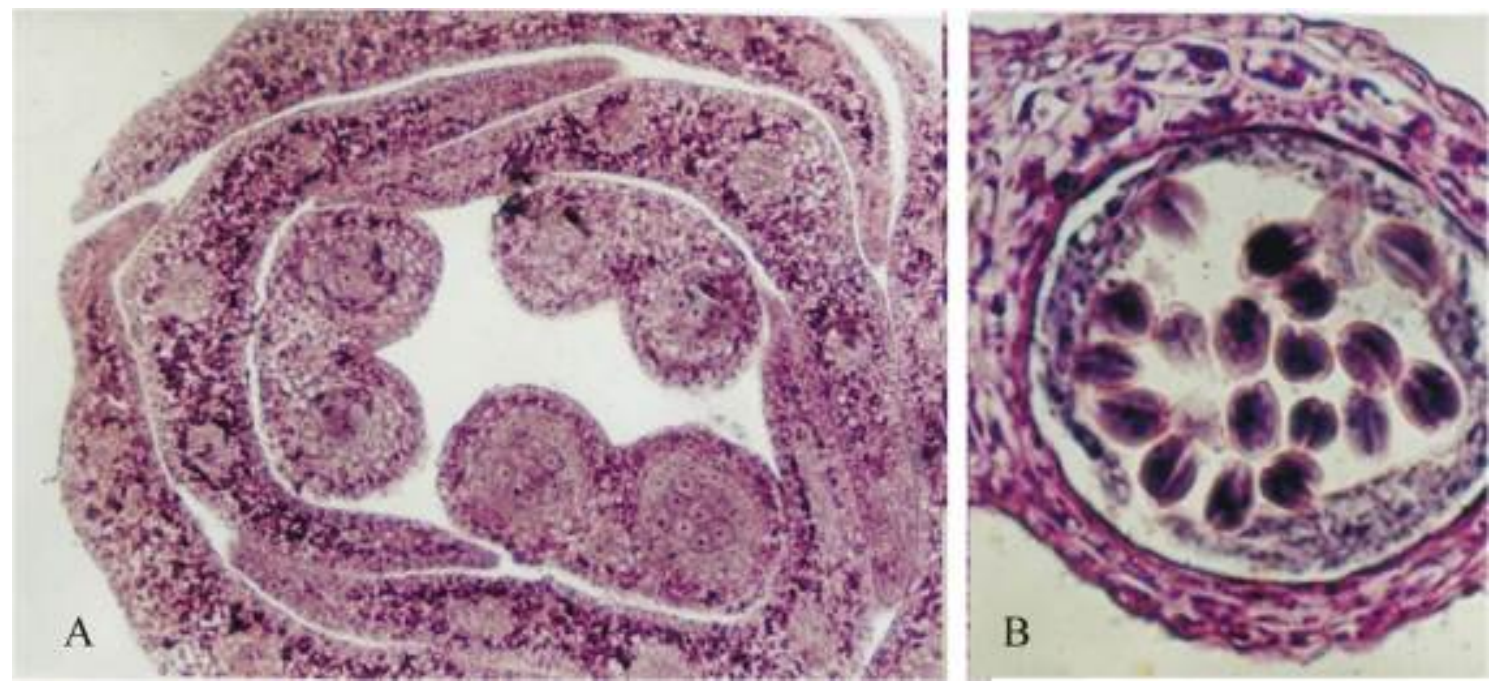

Figure 6. Acanthochlamydaceae. Acanthochlamys bracteata: A. Transection of flower bud, showing stamens with 1-sporangiate thecae. B. Part of stamen in transverse section; pollen mother cells after first meiotic division.
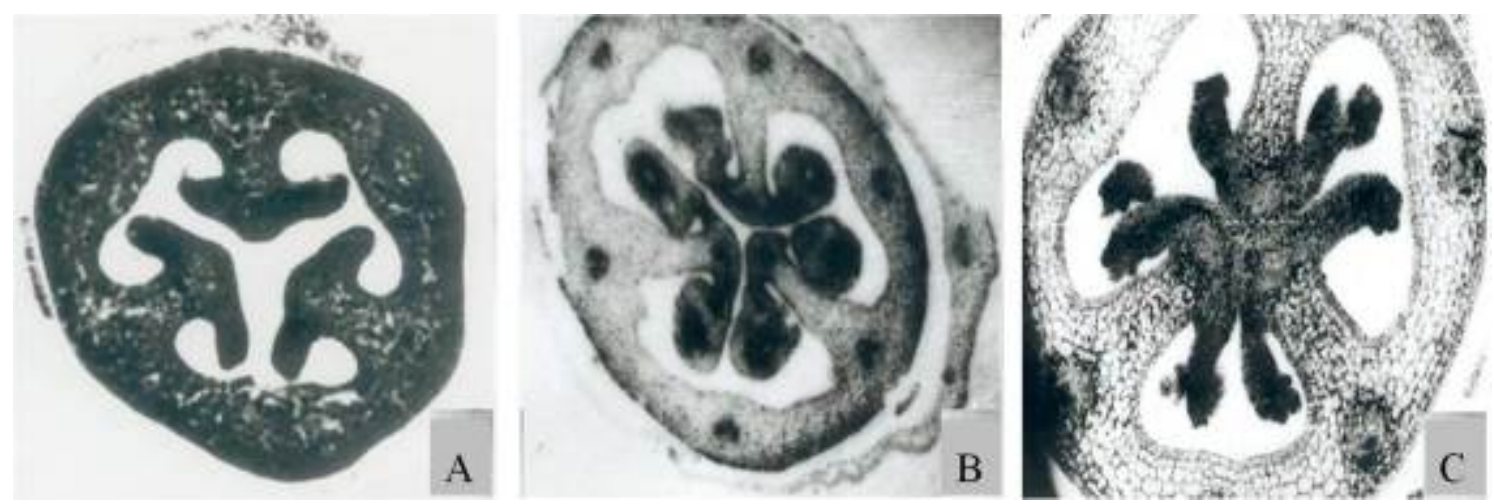

Figure 7. Acanthochlamydaceae. Acanthochlamys bracteata: A. lateral placenta. B. transitional type of placentas between lateral and axile placenta. C. axile placenta (under SEM) 

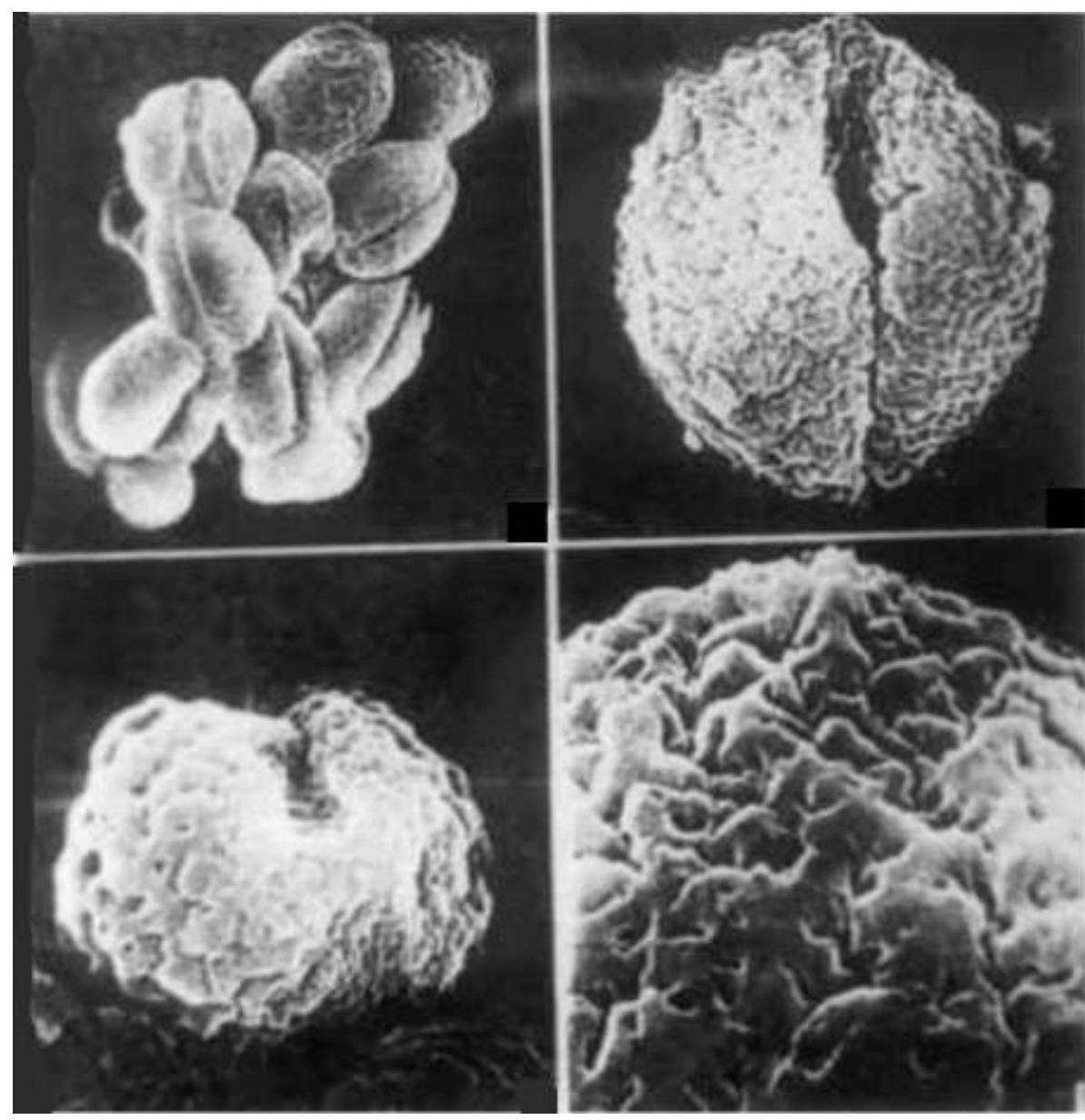

Figure 8. Acanthochlamydaceae. Morphology of pollen in Acanthochlamys bracteata: Pollen of Acanthochlamys bracteata is sulcate, spheroidal and finely verrucae to reticulate.
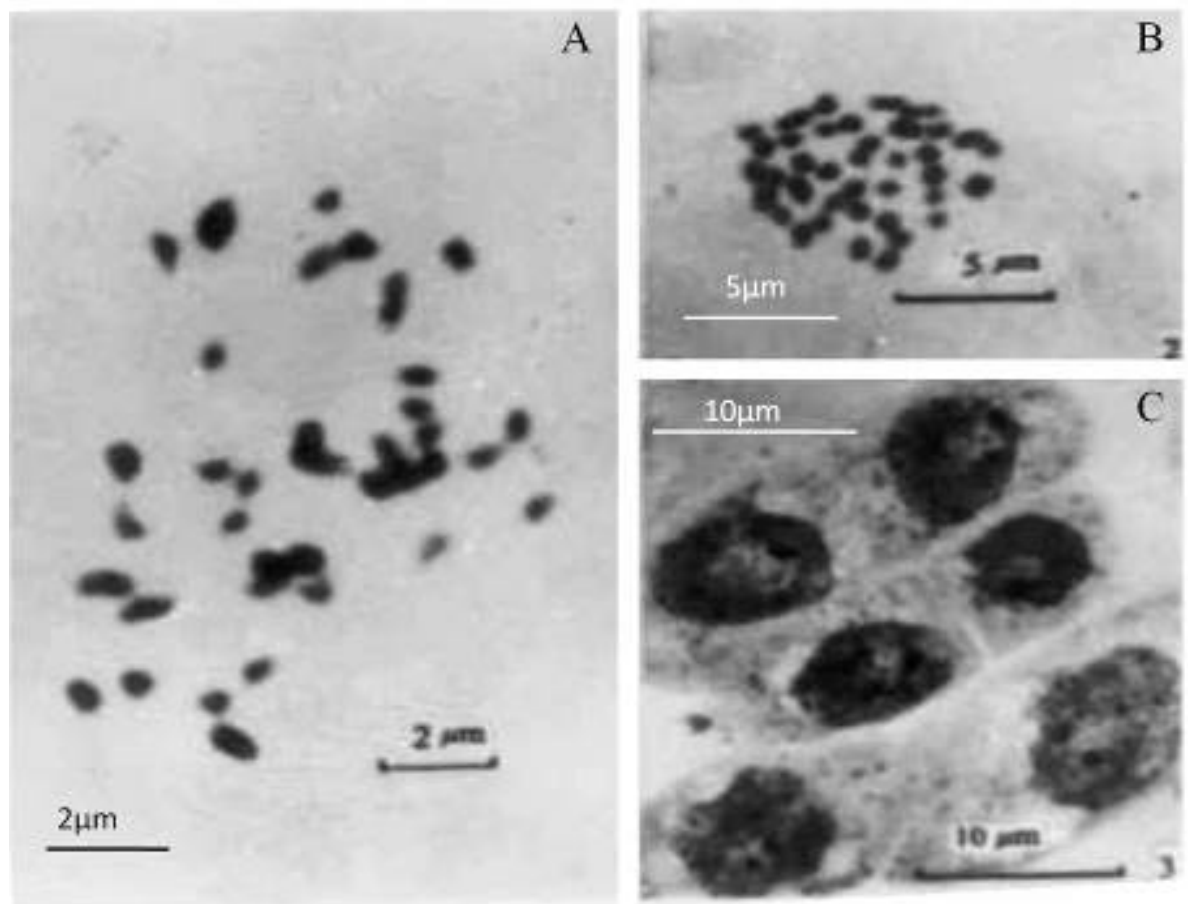

Figure 9. Acanthochlamydaceae. Morphology of chromosome in Acanthochlamys bracteata: A, B. metaphase chromosome in cell division. C. interphase cell 


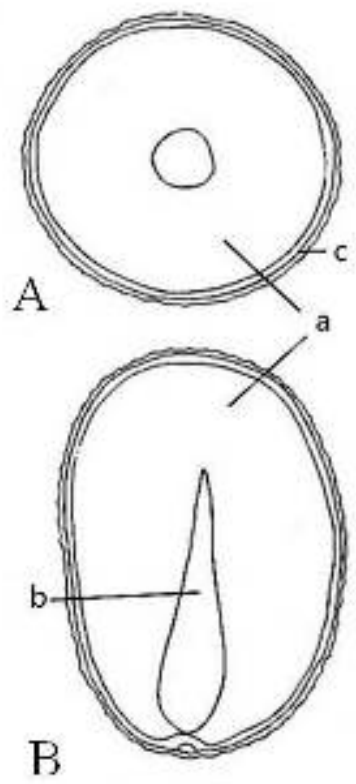

$0.25 \mathrm{~mm}$

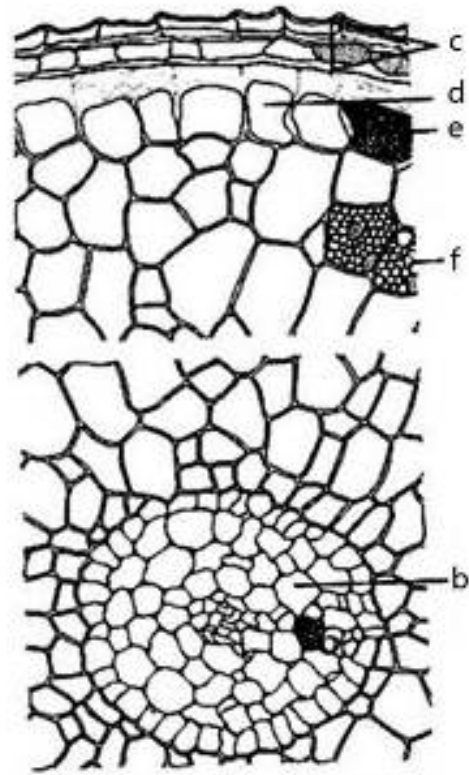

$\mathrm{C}$

$50 \mu \mathrm{m}$

Figure 10. Acanthochlamydaceae. Morphology of seed in Acanthochlamys bracteata. A. Seed, transverse section. B. Seed, longitudinal section. C. as A, enlarged, $a$ endosperm; $b$ embryo; $c$ seed coat; $d$ aleurone layer; $e$ cell filled with aleurone; $f$ cell filled of starch grains.

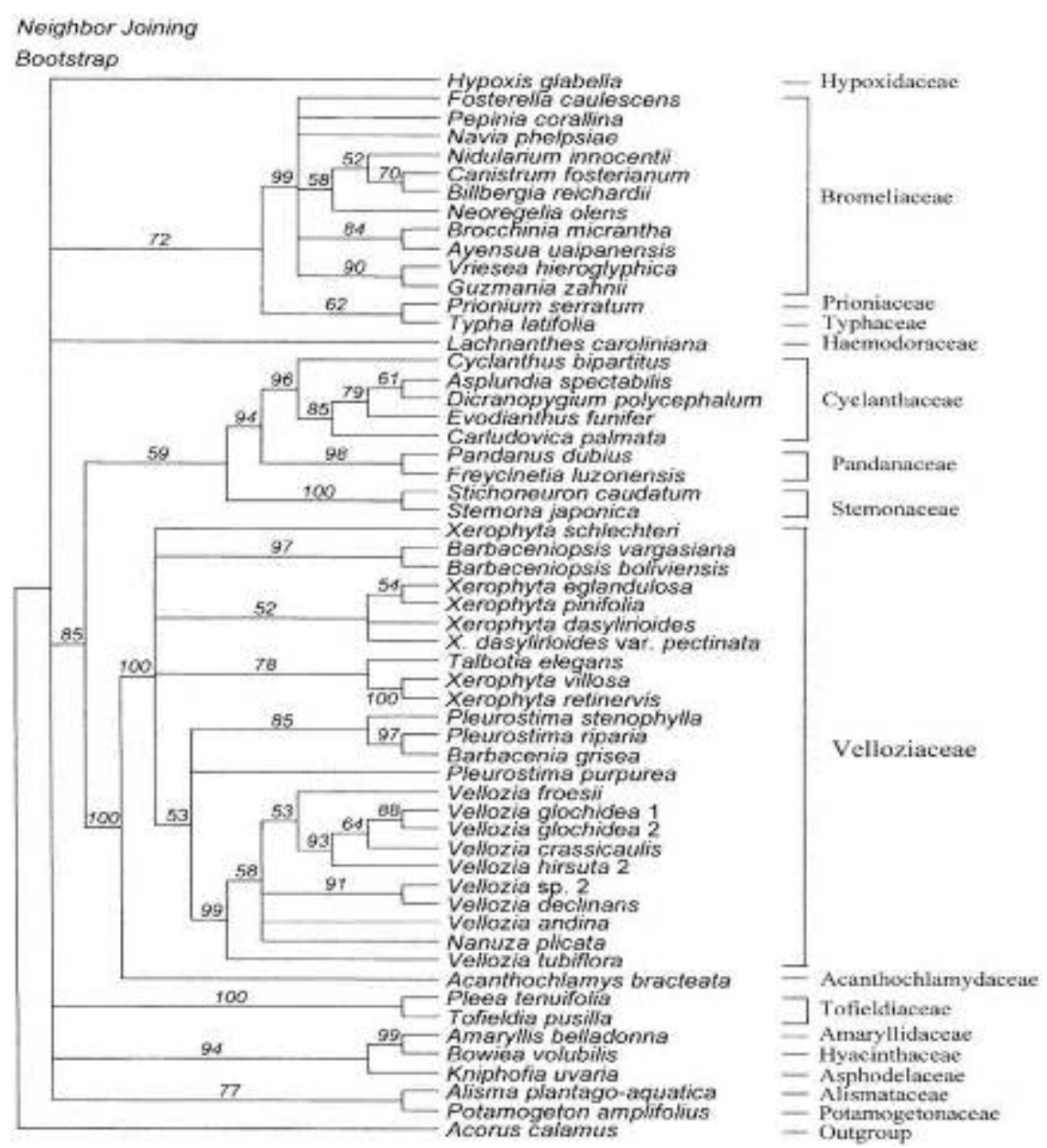

Figure 11. Acanthochlamydaceae. Molecular phylogeny and systematic of the Pandanales inferred from nucleotide sequences of the $r b c \mathrm{~L}$ gene. The data set was analysed by the Neighbor Joining distance method using Kimura 2-parameter as a distance algorithm. The bootstrap cladogram (on 1000 replications) shows a $50 \%$ consensus tree which treats all bifurcations with a bootstrap value lower than $50 \%$ unresolved [11]. Acanthochlamys bracteata and Velloziaceae forming a monophyletic group with and the bootstrap value high to $100 \%$. 

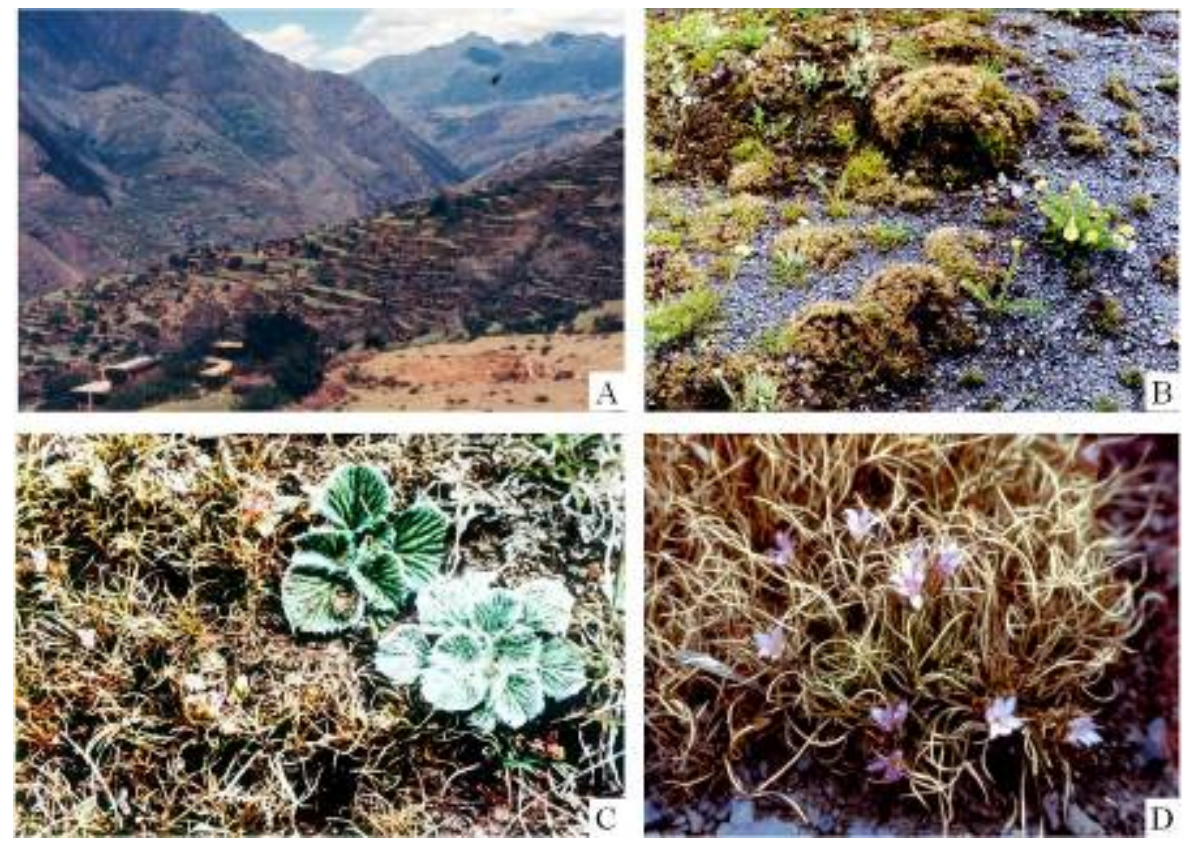

Figure 12. Acanthochlamydaceae. Habitat of Acanthochlamys bracteata (photographed by Bao-chun Gao, 2007). A. Type locality of A. bracteata in Althy, Mount Yazhuo, Commune Yazhuo, Zhaba, Daofu county, Sichuan, China in alt. 2600-3400m. B. A. bracteata grows on barren rocks exposed to sunshine as dominant plant, accompany with Stelera chamaejasme. Pedicularis sp. C. Accompaning plant: Petrocosmea oblate, Cotoneaster buxifolius, Conandron ramondioides. D. Flowering $A$. bracteata.

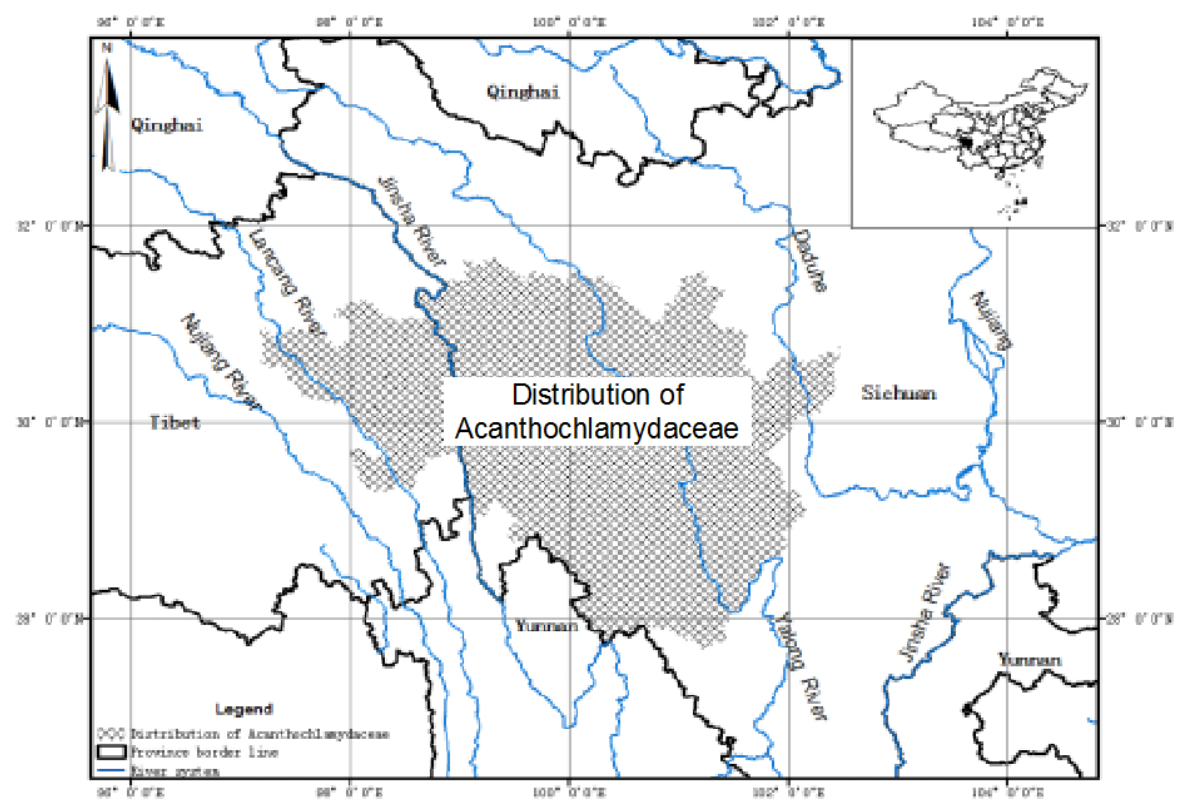

Figure 13. Acanthochlamydaceae. Distribution of Acanthochlamys bracteata

\subsection{Embryology}

The anther is bisporangiate (Fig. 6), and the anther wall is of the monocotyledonous type. The tapetum is glandular. Microsporogenesis is of the Successive type; the pollen tetrads are isobilateral. The mature pollen grains are biortrinucleate. The ovule is anatropous, bitegmic and tenuinucellate (Fig. 7). The development of the embryo sac is of the Polygonum type or Allium type [6]. Fertilization is porogamous and premitotic and endosperm development is unclear [7].

\subsection{Pollen Morphology and Pollination}

The anthesis of Acanthochlamys is very short. The pollen is ellipsoidal (Fig. 8), size 11. $3 \times 17.9 \mu \mathrm{m}$, with an anacolpate, layered obvious, outer layer thinner than inner one, verrucate to reticulate, mesh small. Pollination seems to be mediated by small bees [8]. Pollen of Amaryllidaceae is monosulcate or two sulcate (some genera with 3 or more 
germinal aperture), $17 \times 160 \mu \mathrm{m}$; with outer layer thicker than inner layer, ornamentation changes few. The two families differ each other quite much [8].

\subsection{Karyology}

Chromosome number is $2 \mathrm{n}=38$, chromosome is small (Fig. 9). This is different to Amaryllidaceae and Velloziaceae in chromosome basal number but concord with Aspidistra and Tupistra of Liliaceae[9].

\subsection{Seed Characteristics}

The seeds (Fig. 10) are brown, shining, ellipsoid, $0.75 \times 0.5 \mathrm{~mm}$. The epidermis of the outer integument is collapsed so that the seeds have a grooved, microreticulate surface. The other layer (s) belonging to the outer integument certainly not more than 2 - is/are collapsed. The inner integument is represented by one well developed and another collapsed layers that contain a red-brown content, presumably condensed tannins. Mechanical strength is provided mainly by the thickened periclinal walls of the cell layer immediately beneath the seed coat. This layer contains aleuron and is free of starch. The rest of the endosperm contains starch in the form of composed starch grains. The embryo lies in the middle of the endosperm and reaches $3 / 4$ of the length of the endosperm [2]. The seeds of Acanthochlamys bracteatain natural state have to treat with frozen condition under $-4^{\circ} \mathrm{C}$ for 7 days so as to terminate the period of dormancy [10].

\subsection{Phytochemistry}

Nineteen compounds including triterpenoids, steroids, flavonoids and phenolic acids were isolated from the whole plants of Acanthochlamys bracteata. Among them, one is a novel triterpene and named acanthochlamic acid which was elucidated as 3, 4-seco-3-nor-lup-4(23), 20(29)-dien-2, 28-dioic acid by spectroscopic techniques including $1 \mathrm{D}$ and 2D nuclear magnetic resonance spectroscopy and confirmed by X-ray crystallography[11].

\subsection{Phylogeny}

Our ultrastructural and genetic $(r b c \mathrm{~L})$ studies in the order Pandanales clearly demonstrated a separation of Acanthochlamys from the Velloziaceae and all other families (e.g., Amaryllidaceae), which this genus has been placed previously. The sieve-element plastids of Acanthochlamys differ from those of the Velloziaceae by their lack of loosely-packed crystals and from the Amaryllidaceae and all families of the order Pandanales by their small sizes. In cladistic analyses of the comparative $r b c \mathrm{~L}$ data, Acanthochlamysis suggested affinitive to Velloziaceae (100\% bootstrap supported). Velloziaceae with a support of $100 \%$ bootstrap, and has a further relationship to Amaryllidaceae or any other groups (Fig. 11). It is therefore concluded that the erection of the monotypic endemic family Acanthochlamydaceae made by Prof. Kao [2] is fully supported [12].

\subsection{Affinities}

Originally described by Kao [1] as a member of the Amaryllidaceae, Acanthochlamys was elevated to subfamily rank in Amaryllidaceae by Chen [13]. In 1987, Acanthochlamys was placed in Velloziaceae by Zhengyi Wu, who wrote in Gao[8] that it "...may belong to an ancient family that was never recorded in China and eastern Asia-Velloziaceae". After studying the anatomy, taxonomy, palynology, embryology, karyology, phytochemistry and ecology of Acanthochlamys for nearly 10 years, the profound differences separating the genus from the Amaryllidaceae led $\mathrm{Kao}[2]$ to elevate it to the rank of family. Subsequently, Kao [2] compared Acanthochlamys with Tofieldia and suggested for Acanthochlamys an intermediate position between Tofieldia and Amaryllidaceae. Later, and mainly based on the agreement in chromosome base number, a close relationship of Acanthochlamys to Convallariaceae (Aspidistra and Tupistra) was considered [14]; however, this suggestion is not supported by morphological evidence and is no longer upheld. In the $r b c \mathrm{~L}$ analysis by Chase et al.[15]. Acanthochlamys appeared in a strongly supported branch together with the Velloziaceae.

Indeed, a possible relationship should be considered with all those families that share with Acanthochlamys the possession of epigyny and starch accumulation in the endosperm, viz. Bromeliaceae, Haemdoraceae and Velloziaceae. It is significant that these three families agree with Acanthochlamys in having starch grains composed of relatively few elements in the endosperm. Among these families, the Bromeliaceae differ too much from Acanthochlamys in their perianth differentiated into calyx and corolla and their epidermal cells containing large silica bodies. The remaining two families agree with Acanthochlamys in the collapsed testa and 2-layered tegmen, the Velloziaceae also in the bisporangiate anthers, and additionally the Haemodoraceae in the thickened outer periclinal wall of the aleuron layer. Also the Xyridaceae are similar in several respects, although they are truly "enantioblastic" and have hypogynous flowers.

Among all families compared here with Acanthochlamys, the absence of cell wall-bound ferulate is shared only with the Velloziaceae. Thus, the morphological data point in the same direction as the molecular analysis, although the relationship between Acanthochlamys and the Velloziaceaemay is not very close. Acanthochlamys is more close to Velloziaceae from multi-subject material, e.g. Tenuinucellate, inferior ovary, unisulcate pollen grains, xerophytic habit, but there is also a lot of difference between the two taxa, as showed in following table (Table 2). Since Acanthochlamys bracteata was discovered, the disputations focused on the systematic position rank of the genus 
Acanthochlamys. Also there are many treatments, the final opinion is that Acanthochlamys is affinitive with Velloziaceae, but whether a family or being a genus of Velloziaceae should be given to it is divergent. According to above-mentioned researching work, it is necessary to give a family rank to it and it is better to consider the new family in Velloziales---Acanthochlamydaceae

\subsection{Distribution and Habitat}

Acanthochlamys bracteata is restricted to the Hengduan Mountains at the SE margin of the Plateau of SW China (Xiangcheng, Daofu (Fig. 12A), Daocheng, Luhuo, Yajiang and Kangding of W Sichuan to Chaya of Tibet), where it occurs in the subalpine shrub-meadow region at an altitude of $2700-3500 \mathrm{~m}$ and from $29-31 \mathrm{~N}$ and $96-103 \mathrm{E}$, mainly in Xianshui River in middle reaches of Yalongguan River at an altitude of $2700-3500 \mathrm{~m}$, the valleys are steep, soil barren with bare rocks, mostly killas and metamorphic rocks(Fig. 13). The appearance of the community varies according to different seasons, basically sparsely vegetated, normally early plants with pricks, indumentums, small leaves, and usually volatile oil. Main species are listed here: Sophora davidii, Bauhinia brachycarpa var. microphylla, Berberis sp., Rosa sp., various Clematis potaninii, Anemone obtusiloba, Taraxacum mongolicum; Acanthochlamy sbracteata (Fig. 12D) grows on rocks as a dominant species, accompany with Stellera chamaejasme (Fig. 12B), Petrocosmea oblata (Fig. 12C), Festuca ovina, Arundinella hookeri and so on[8] (Table 1). Acanthochlamys grows on relatively hard soil, which is high in $\mathrm{Zn}, \mathrm{Cu}$ and $\mathrm{Pb}$. Other elements including $\mathrm{Al}, \mathrm{As}, \mathrm{Fe}, \mathrm{K}, \mathrm{Na}, \mathrm{Mg}, \mathrm{Mn}, \mathrm{Ca}$ and $\mathrm{P}$ are in low concentrations low [16].

Table 1. List of the species in the community of Acanthochlamys bracteata

\begin{tabular}{|c|c|c|c|}
\hline Scientific name & Family & Scientific name & Family \\
\hline Acanthochlamys bracteata & Acanthochlamydaceae & Leontopodium wilsonii & Compositae \\
\hline Aconitum sp. & Ranunculaceae & Lotus corniculatus & Leguminosae \\
\hline Anaphalis yunnanensis & Compositae & Lycopodium sp. & Lycopodiaceae \\
\hline Andropogon yunnanensis & Gramineae & Microula sp. & Boraginaceae \\
\hline Androsace integra & Primulaceae & Onosma adenopus & Boraginaceae \\
\hline Androsace integra & Primulaceae & Orlhoraptnim roylei & Gramineae \\
\hline Anemone obtusiloba & Ranunculaceae & Pedicularis sp. & Scrophulariaceae \\
\hline Arisaema consanguineum & Araceae & Petrocosmea oblata & Gesneriaceae \\
\hline Artemisia desertorum & Compositae & Polygonum viviparum & Polygonoideae \\
\hline Artemisia vestita & Compositae & Polytrichum commune & Polytrichaceae \\
\hline Arundinella hookeri & Gramineae & Potentilla bifurca & Rosaceae \\
\hline Aster tongolensis & Compositae & Potentilla chinesis & Rosaceae \\
\hline Astragalus sp. & Leguminosae & Potentilla fruticosa var. albicans & Rosaceae \\
\hline Bauhinia brachycarpa var. microphylla & Leguminosae & Potentilla saundersiana & Rosaceae \\
\hline Berberis prattii & Berberidaceae & Rosa soulieana & Rosaceae \\
\hline Campylotropis yajiangensis & Leguminosae & Selaginella pulvinata & Selaginellaceae \\
\hline Cirsium botryodes & Compositae & Selaginella tamariscina & Selaginellaceae \\
\hline Corallodiscus flabellatus & Gesneriaceae & Sophora davidii & Leguminosae \\
\hline Cotoneaster buxifolius & Rosaceae & Spiraea alpina & Rosaceae \\
\hline Cyananthus hookeri & Campanulaceae & Spiranthes lancea & Orchidaceae \\
\hline Cynanchum forrestii & Asclepiadaceae & Stellera chamaejasme & Thymelaeaceae \\
\hline Elsholtzia rugulosa & Labiatae & Taraxacum mongolicum & Compositae \\
\hline Entodon concinnus & Entodontaceae & Taraxacum parvulum & Compositae \\
\hline Festuca ovina & Gramineae & Thalictrum alpinum & Ranunculaceae \\
\hline Kobresia humilis & Cyperaceae & Viola sp. & Violaceae \\
\hline Leibnitziaan andria & Compositae & Youngia sp. & Compositae \\
\hline
\end{tabular}


Table 2. Comparison of morphological characters between Acanthochlamydaceae and Velloziaceae

\begin{tabular}{|c|c|c|c|}
\hline Characters & & Acanthochlamydaceae & Velloziaceae \\
\hline \multirow{6}{*}{ Anatomy } & Root & protostele tetrarch, rarely triarch & Medullated 8-arch (Xerophyta humilis) \\
\hline & Scape & $\begin{array}{l}\text { The structure of the scape is similar to that of a leaf } \\
\text { ensheathing a rhizome }\end{array}$ & $\begin{array}{c}6 \text { vascular bundles in a circle, vascular bundles } \\
\text { similar to those of leaf }\end{array}$ \\
\hline & Leaf & $\begin{array}{l}\text { The mesophyll lacks differentiation into palisade and spongy } \\
\text { tissue. The midrib of the leaf is composed of } 2 \text { vascular } \\
\text { bundles, which are arranged "back to back" with their xylem } \\
\text { portions }\end{array}$ & $\begin{array}{c}6 \text { vascular bundles, each with one xylem unit and } \\
\text { phloem units at both ends, mesophyll more or } \\
\text { less differentiated }\end{array}$ \\
\hline & Habit & xerophytic dwarf herb & xerophytic shrub, subshrub or herb \\
\hline & Flower & $\begin{array}{l}\text { Inflorescence capitate, with aristate bracts and bractlets; } \\
\text { perianth lobes 6; stamens 6, filament merges tapel, nearly } \\
\text { absent }\end{array}$ & $\begin{array}{l}\text { Flowers often single copying APG website; } \\
\text { perianth lobes glandular; stamens } 6 \text {, or } \\
\text { numerous; and in } 6 \text { bundles }\end{array}$ \\
\hline & Placentation & $\begin{array}{l}\text { Parietal placenta in upper part of the ovary and axile placenta } \\
\text { at lower part. }\end{array}$ & axile placenta, placentae lobed spreading. \\
\hline \multirow{3}{*}{ Embryology } & Nucellus & tenuinucellate, no nucellar cap & tenuinucellate, nucellar cap \\
\hline & Embryo sac & Polygonum or Allium type & Polygonum type \\
\hline & Endosperm & nuclear & helobial \\
\hline $\begin{array}{c}\text { Chromosome } \\
\text { number }\end{array}$ & & $2 \mathrm{n}=38, \mathrm{n}=19$ & $\begin{array}{c}\text { Vellozia: } \mathrm{n}=7,8 ; \text { Barbacenia: } \mathrm{n}=17 ; \text { Xerophyta: } \\
\mathrm{n}=24 ; \text { Talbotia: } \mathrm{n}=24\end{array}$ \\
\hline $\begin{array}{l}\text { Geographic } \\
\text { distribution }\end{array}$ & & W Sichuan and SE Tibet & $\begin{array}{l}\text { Southern tip of the Arabian Peninsula, Tropical } \\
\text { Africa, Madagascar and Tropical America. }\end{array}$ \\
\hline
\end{tabular}

\section{Acknowledgments}

The author deeply appreciates the hard working world famous botanist Klause Kubitzki, the systematics research of this family is finished in his help, and he is the first one to confirm the taxonomy position of Acanthochlamydaceae in his work The Families and Genera of Vascular Plants (1998),which encouraged me a lot. The author thanks plant taxonomist, Prof. Zheng-yi Wu, who confirm the erection of Acanthochlamydaceae in 2003; Molecular biologist H.D. Behnke, from Germany and many anonymous staffs for their help during the collection. Our special thanks give to Prof. Guo-yue Zhong from Jiangxi University of Traditional Chinese Medicine, who made the illustrations and SEM photographs in this work. Lots of novel samples researches were completed with the assistance of Velloziaceaespecialist, Brazil botanist Nanuza L. de Menezes. The author also thanks Lisa M. Campbell who helped me during my journey to the international conference of Monocots V, and also wrote and revised papers; her highly responsible review on this paper is extremely helpful to me, the author is truly grateful! In addition, Josef Bogner etc. made contributions to the research of Acanthochlamydaceae, and the author thanks them very much. The authors would also like to thank Prof. Ping Li, Ya Tang, Hai-yan Na from Sichuan University, Prof. Li-sheng Ding, Ling Wu, Qian Wang from Chengdu Institute of Biology, and Chinese Academy of Science. The author thanks Prof. Yong-hong Zhou, Prof. Yan-li Lu from Sichuan Agricultural University for their help in building this family. Here are also special thanks to Dr. Xiao-yu Dong in Institute of Botany, Jiangsu Province and Chinese Academy of Sciences, who helped to translate and format the manuscript. In the end, the author specially thanks everybody who concerns and supports the research of Acanthochlamys for their help in the 30 years' research works, and the author sincerely welcome all over the world to botanist to Hengduan Mountains in Sichuan, China to work on Acanthochlamys, which is a group deserve exploration. Thank you very much!

\section{REFERENCES}

[1] P. C. Kao. A new genus of Amaryllideae. Plant Taxon Res, Chengdu Biol. Ins. Acad. Sin. Vol.1, 1-3, pl. I-II, 1980. (In Chinese and Latin).

[2] P. C. Kao. Acanthochlamydaceae: a new monocotyledonous family. In: P. C. Kao, Z. M. Tan, eds. Sichuanica Flora, Sichuan National Publishing House, Chengdun, 1989. (In Chinese and English)

[3] N.L. Meneze, B.C. Gao, C.G. Silva. The Extraordinary Acanthochlamys bracteata P.C. Kao. Monocots V. Congress. New York, American, abstracts 83, 2013.

[4] B.C. Gao. Systematic study of Acanthochlamydaceae. Monocots V. Congress. New York, American, abstracts 82, 2013.

[5] B.C. Gao. Acanthochlamydaceae. Monocots V. Congress. New York, American, abstracts 81, 2013.

[6] P. Li, B. C. Gao, F. Chen, H. X. Luo. Studies on morphology and embryology of Acanthochlamys bracteata. II: The anther and ovule development. Bulletin of Botanical Research, Vol.12, 389-395, 1992. (In Chinese with English summary)

[7] P. Li, B. C. Gao. Studies on morphology of Acanthochlamys bracteata. III: The investigation on double fertilization, embryogenesis and endosperm development of Acanthochlamys bracteata. Journal of Sichuan University (Science ed.), Vol.30, No.4. 260-263, 1993. (In Chinese with English summary) 
[8] B. C. Gao. The sociological characteristics and pollen morphology of Acanthochlamys bracteata, Acta Botanica Yunnanica, Vol. 9, 401-405, 1987. (In Chinese with English summary)

[9] P. C. Kao, Y. Tang, W. Guo. A cytological study of Acanthochlamys bracteata (Acanthochlamydaceae). Acta Phytotaxonomica Sinica, Vol. 31, 42-44, 1993. (In Chinese with English summary)

[10] X. L. Hu, B. C. Gao, H. Y. Na. In vitro seed germination of Acanthochlamys bracteata (Acanthochlamydoiceae). Chinese Journal of Applied and Environmental Biology, Vol. 14, 450-453, 2008. (In Chinese with English summary)

[11] B. J. Li, B. C. Gao, S. L. Peng, X. Liao, L. S. Ding. Chemical constituents from Acanthochlamys bracteata. Chinese Journal of Chemistry, Vol.23, 933-936, 2005.

[12] H. D. Behnke, J. Treutlein, M. Wink, K. Kramer, C. Schneider, P. C. Kao. Systematics and evolution of Velloziaceae, with special reference to sieve-element plastids and $r b c \mathrm{~L}$ sequence data. Botanical Journal of the Linnean Society, Vol. 134, 93-129, 2000.

[13] S. C. Chen. Acanthochlamydoideae: a new subfamily of Amaryllidaceae, Acta Phytotaxonomica Sinica, Vol.19, No.3, 323-329, 1981. (In Chinese with English summary)

[14] B. C. Gao. Confirmation of Acanthochlamydaceae, a new proposed monocotyledons family and its systematic position. Acta Botanica Yunnanica, Vol. 20, No. 1, 23-31, 1998. (In Chinese with English summary)

[15] M. W. Chase, M. R. Duvall, H. G. Hills. Molecular phylogenetics of Lilianac. In: P. J. Rudall, P. J. Cribb, D. F. Cutler, C. J. Humphries, eds. Monocotyledons: Systematics and Evolution, London: Royal Botanic Gardens Kew, 1995.

[16] Q. Wang, D. Zhu, N. Wu, P. Luo. Plant community structure and soil element content in Acanthochlamys bracteata habitats in Daofu County, China, Chinese Journal of Applied and Environmental Biology, Vol. 15, 1-7, 2009. 